\title{
Poder local e "voz do povo": territorialidade e política dos índios nas repúblicas de maioria indígena do Espírito Santo, 1760-1822
}

\author{
Vânia Maria Losada Moreira[1]
}

\begin{abstract}
Resumo
As reformas pombalinas da década de 1750 procuraram inovar as relações sociais no mundo colonial ao propor a equiparação de índios e portugueses em termos de direitos políticos e distinção social. O objetivo do artigo é refletir sobre a participação política dos índios nos governos locais de suas vilas a partir da vigência do Diretório pombalino, considerando especialmente as experiências dos índios da capitania do Espírito Santo.
\end{abstract}

Palavras-chave: índios; poder local; terras indígenas.

Local authority and "the people's voice": Territoriality and the indigenous policy in the republics of indigenous majority in Espirito Santo, 1760-1822

\begin{abstract}
The pombaline reforms during the decade of 1750 tried to modernize the social relationships in the colonial world by proposing to equate the indigenous peoples of Brazil with the Portuguese in terms of political rights and social distinction. This paper reflects on the political participation of the native Brazilians in the local authority of their villages during marquis of Pombal's Diretório (Directorate), focusing mainly on their experiences in the captaincy of Espírito Santo.
\end{abstract}

Keywords: indigenous people; local authority; indigenous lands.

Pouvoir local et "voix du peuple": territorialité et politique des indiens dans les républiques à majorité indienne de l'Espirito Santo, 1760-1822

\section{Résumé}

Les réformes pombaliennes des années 1750, en proposant l'égalité entre les indiens et les Portugais dans les domaines des droits politiques et de la distinction sociale, ont eu pour but d'innover les rapports sociaux dans le monde colonial. L'objectif de cet article est de penser la participation politique des indiens dans les gouvernements locaux de leurs villages à partir de l'instauration du Diretório pombalien, en considérant tout particulièrement les expériences des indiens de l'Espírito Santo.

Mots-clés : indiens; pouvoir local; terres indiennes.

Poder local y "voz del pueblo": territorialidad y política de los índios en las repúblicas de mayoría indígena de Espírito Santo, 1760-1822

\section{Resumen}

Las reformas implantadas por el marqués de Pombal en la década de 1750 buscaron introducir innovaciones en las relaciones sociales en el mundo colonial, al proponer la equiparación de indios y portugueses en términos de derechos políticos y distinción social. El objetivo de este artículo es reflexionar sobre la participación política de los índios en los gobiernos locales de sus villas, a partir de la vigência del Diretório pombalino, analizando especialmente las experiencias de los indios de la capitanía de Espírito Santo.

Palabras clave: indios; poder local; tierras indígenas. 
interpretação de que os povos indígenas da costa do Brasil não tinham uma verdadeira vida civil (isto é, política e social) apareceu bem cedo na cultura erudita europeia. Em 1502, por exemplo, Américo Vespúcio escreveu que os índios viviam "segundo a natureza [...] sem rei e sem obedecer a ninguém” (apud Pompa, 2003, p. 43). Posteriormente, outros relatos repetiriam o mesmo argumento e, como observou Cristina Pompa, não propriamente por uma "coincidência de fatos observados", mas principalmente em razão "da circulação de relatos entre os escritores" (Pompa, 2003, p. 43).

A fórmula que ficou mais conhecida foi a deixada por Pero de Magalhães Gândavo, em História da província Santa Cruz (1576). Segundo ele, a língua dos índios da costa do Brasil carecia “[...] de três letras, convém a saber, não se acha nela $f$, nem $l$, nem $R$, cousa digna de espanto, porque assi não têm Fé, nem Lei, nem Rei: e desta maneira vivem desordenadamente [...]" (apud Alcides, 2010, p. 39). Mais de dois séculos depois, a etnografia de Johann Baptist von Spix e Karl Friedrich Philipp von Martius renovou o velho argumento segundo as teorias racistas crescentemente aceitas ao longo do século XIX. Para eles, os índios eram "homens da natureza" (Spix e Martius, 1981, p. 236) que viviam "[...] fora de qualquer vínculo social, nem em associação republicana nem patriarcal" (Spix e Martius, 1981, p. 232). Por isso mesmo, a "raça" permanecia "ignorante de toda a vocação nobre da humanidade" (Spix e Martius, 1981, p. 239). ${ }^{2}$

De Vespúcio a Martius, observa-se que os índios não se encaixavam nem na imagem do animal político aristotélico (zõonpolitikon) nem na tradução dessa ideia feita por São Tomás de Aquino: "homo est naturaliter politicus, id est, socialis ('o homem é, por natureza, político, isto é, social')" (Arendt, 2010, p. 27). Tomando como certo que eles viviam fora do genuíno estado social porque não tinham organização política, lei e religião, a conquista civil e espiritual dos índios foi justificada tendo por base a ideia de obrigação moral de os povos cristãos e civilizados darem aos índios aquilo de que supostamente careciam: a verdadeira vida civil/social e a salvação de suas almas por meio da conversão ao catolicismo. Nesse processo, criou-se um vasto corpo normativo acerca dos direitos e das obrigações dos índios com o fito de acomodar expectativas diversas, e até mesmo contraditórias, alimentadas por moradores, missionários, autoridades régias e pelos próprios índios, que, progressivamente, também passaram a fazer parte do mundo colonial.

O objetivo deste artigo é refletir sobre a participação política dos índios no governo local de suas vilas a partir da vigência do Diretório pombalino. Para isso, serão exploradas as experiências indígenas na capitania do Espírito Santo, problematizadas as práticas sociais e políticas, rastreando-se as agendas, os interesses e o protagonismo dos índios na vida política colonial.

${ }^{2}$ Vale registrar que as acepções de "raça" nos séculos XVIII e XIX são muito distintas (Viana, 2007; Schwarcz, 1993). No mundo colonial do setecentos, a categoria era acionada fundamentalmente para destacar laços reais ou presumidos de ancestralidade e consanguinidade, e não um grupo biológico com traços determinantes de seu caráter, tal como já aparece em Spix e Martius. 


\section{Inferioridade, tutela e participação política}

Em sociedades juridicamente estratificadas, como eram as de Antigo Regime no reino e na América portuguesa, a lei e o direito cumpriam um papel importante na definição de privilégios e obrigações e na regulação das hierarquias e relações sociais (Godinho, 1977, p. 74; Hespanha, 2010a, p. 18). Até as reformas pombalinas da década de 1750, a legislação acerca dos índios oscilou bastante: permitiu o cativeiro por resgate e guerras justas em diferentes momentos e partes da colônia (Perrone-Moisés, 1992); tolerou a administração particular dos índios por moradores (Monteiro, 1994); e também garantiu a vida comunitária em aldeamentos, sob a tutela de missionários (Almeida, 2003). Ao fim e ao cabo, a propalada liberdade dos índios, defendida em cartas régias, alvarás e regimentos, ficou particularmente garantida aos índios aldeados, que tinham terra própria e missionários para catequizá-los, e era estritamente regulamentada, impondo-lhes diferentes modalidades de trabalho obrigatório devido à Coroa e aos moradores.

\section{A conquista civil e espiritual dos índios foi justificada tendo por base a ideia de obrigação moral de os povos cristãos e civilizados darem aos índios aquilo de que supostamente careciam}

As novas leis e recomendações editadas durante o consulado pombalino procuraram consolidar a liberdade dos índios e inovar as relações sociais, principalmente por meio da proposta de equiparação de índios e portugueses em termos de privilégios políticos e distinção social. Podem-se dividir as reformas pombalinas acerca dos índios em dois momentos, sendo o primeiro o ano 1755. O alvará de 4 de abril garantiu que contraentes portugueses de casamento com índios, e seus descendentes, ficassem livres de "infâmia" e fossem habilitados a receber terras, empregos e outras honrarias; proibindo-se, também, que os índios fossem tratados com termos ou expressões pejorativas. Pouco depois, a Lei das Liberdades, de 6 de junho, declarou a plena liberdade dos índios com relação às suas pessoas, aos seus bens e ao seu comércio; enquanto o alvará de 7 de junho aboliu o poder temporal dos missionários sobre eles, ordenando, ainda, que os índios, quando considerados idôneos, fossem preferidos para ocupar os cargos de juízes ordinários, vereadores e oficiais de justiça de suas respectivas vilas (Lopes, 2005, p. 70). Com exceção da lei de 4 de abril, que era extensiva a todos os índios da América portuguesa, as de 6 e 7 de junho foram inicialmente projetadas para reger a vida dos índios do Grão-Pará e Maranhão.

As leis de 1755 ganham mais clareza quando lidas e interpretadas à luz dos interesses geopolíticos lusitanos, especialmente ao longo das negociações do Tratado de Madri. Nesse período, o secretário de Estado da Guerra e Negócios 
Estrangeiros, Sebastião José de Carvalho e Melo - futuro marquês de Pombal -, demonstrou nítida intenção em atrair os índios para os domínios portugueses com o fito de garantir as pretensões territoriais de Portugal (Garcia, 2009, p. 32). Para isso, sugeriu ao general Gomes Freire de Andrade, então à frente da comissão demarcadora do Tratado de Madri, um conjunto de medidas para dar-lhes condições de vida na América portuguesa superiores e mais favoráveis às que dispunham na América espanhola (Garcia, 2009, p. 33). Pouco depois, parte dessas sugestões foram consagradas no corpo normativo de 1755 . $^{3}$

O segundo momento refere-se aos anos 1757 e 1758. As normas editadas nesse período procuraram, fundamentalmente, restringir e adaptar a ampla liberdade concedida aos índios do Grão-Pará e Maranhão à realidade colonial e às demandas dos moradores por trabalhadores indígenas. Afinal, a liberdade e os novos direitos dos índios, que tanto serviam ao proselitismo político lusitano no processo demarcatório das fronteiras, ameaçavam transformar-se no pomo da revolta dos colonos, especialmente no norte. De acordo com Mauro César Coelho:

Em carta enviada ao ministro Sebastião José de Carvalho e Mello, em fins de 1755, o bispo D. Miguel de Bulhões, governador interino da Capitania do Grão-Pará, [...] argumentava que a libertação dos índios poderia acarretar o desmantelamento da já precária economia da colônia. Libertá-los, sem qualquer instrumento que os obrigassem ao trabalho, despovoaria os engenhos e as lavouras e provocaria, ao final, a revolta dos colonos. (Coelho, 2007, p. 31)

Assim, em 3 de maio de 1757, a plena liberdade e a capacidade governativa, recém-reconhecidas aos índios da Amazônia portuguesa, foram redefinidas, diminuídas e regulamentadas por meio do Diretório que se deve observar nas povoações dos índios do Pará e Maranhão, enquanto Sua Majestade não mandar ao contrário. ${ }^{4}$ Pouco depois, também os índios do Brasil passaram a ser regidos pelas mesmas leis: o alvará de 8 de maio de 1758 estendeu a todos os índios do Brasil as leis de 6 e 7 de junho de 1755, enquanto o alvará de 17 de agosto estendeu a aplicação do Diretório.

O Diretório foi um instrumento legal criado sob a influência das ideias e experiências de Francisco Xavier de Mendonça Furtado, irmão de Carvalho e Mello, enquanto esteve à frente da governança do Grão-Pará. Dedicado a operacionalizar as instruções "públicas" e "secretas" que recebeu em Lisboa, em 1751 - que, entre outros pontos, recomendava conceder liberdade aos índios, equiparando-os aos portugueses -, Mendonça Furtado mostrou-se também sensível às demandas das elites locais, resistentes ao fim do cativeiro dos índios (Coelho, 2007, p. 32). Externou ao irmão as dificuldades locais à plena realização das instruções e sugeriu superar o impasse por meio da instituição de

${ }^{3}$ Em 1751, Francisco Xavier Mendonça de Furtado, capitão-general do estado do Grão-Pará e Maranhão e irmão de Pombal, também recebeu instruções "secretas" acerca de como lidar com índios, semelhantes às recebidas por Gomes Freire (Coelho, 2007, p. 32).

${ }^{4}$ Espírito Santo. Livro tombo da vila de Nova Almeida. Vitória: Imprensa Oficial do Espírito Santo, 1945. 
um regime de tutela, por ele experimentado no processo de criação da vila de Borba, a Nova, erigida sobre a aldeia do Trocano. Nascia, desse modo, a figura do "diretor", que deveria, por um lado, auxiliar os índios no processo de vivência e aquisição da liberdade e autonomia recém-reconhecidas em lei e, por outro, garantir que os índios continuassem prestando serviços à Coroa e aos moradores (Coelho, 2007, p. 38).

No Diretório, os índios foram considerados insuficientemente "civilizados" e, por isso mesmo, incapazes de exercer plenamente o governo de si e de suas famílias. Baseado nesse argumento, instituiu-se o cargo de "diretores de índios" para garantir a aplicação do Diretório, controlando-os enquanto não fossem considerados plenamente capazes. ${ }^{5}$ Desse modo, reintroduziu-se e renovou-se o velho argumento da relativa inferioridade civilizacional dos índios na legislação, apenas temporária e extraordinariamente abolido do corpo normativo no intermezzo entre 6 e 7 de junho de 1755 e 3 de maio de 1757. Além disso, detalharam-se as formas de trabalho obrigatório a que todos os índios estavam sujeitos no gozo de suas liberdades.

Apesar da reintrodução do princípio da tutela e da concepção de relativa inferioridade (civilizacional) dos índios, eles continuaram gozando daquilo que António Manuel Hespanha qualificou de as bem-aventuranças da inferioridade na sociedade do Antigo Regime português e colonial (Hespanha, 2010a). No caso dos índios, as bem-aventuranças se traduziam especialmente nos direitos de liberdade, de domínio e posse territorial e de peticionar à Coroa em busca de justiça e reparação. E, depois das reformas pombalinas de 1755, acrescentou-se outro direito importante, diminuído pelo Diretório, mas não abolido: o do autogoverno, consubstanciado na preferência e no privilégio de participação no governo civil, judicial e militar de suas vilas e povoações.

A presença de diretores restringiu a liberdade dos índios, mas, como a historiografia tem demonstrado, não eliminou o protagonismo social e político ameríndio, que se manifestou de modo variado e de acordo com as potencialidades das circunstâncias locais. Anos mais tarte, a carta régia de 12 de maio de 1798, criticando severamente a atuação dos diretores de índios na América portuguesa, aboliu o Diretório e ditou outras providências, inaugurando um período bastante atípico na história dos índios, pois aqueles que moravam em vilas e povoados ficaram legalmente livres de tutela ${ }^{6}$ Desse ponto de vista, a carta régia pode ser interpretada como uma medida de justiça e reparação que, ao extinguir o Diretório, devolvia aos índios a capacidade plena de autogoverno primeiramente instituída pela lei de 7 de junho de 1755 (Moreira, 2010).

Vale frisar, contudo, duas questões importantes: a carta régia assegurou mecanismos para continuar obtendo o trabalho obrigatório dos índios (Sampaio, 2007, p. 42) e não estendeu o privilégio do autogoverno aos povos independentes dos sertões. Estes continuaram sendo descritos como nações que viviam

5 Diretório... §1‥ Ibidem, p. 56

${ }^{6}$ Cópia da carta régia de 12 de maio de 1798 sobre a civilização dos índios enviada a Antônio Peres da Silva Pontes em 29 de agosto de 1798. In: Oliveira (1856, p. 161-335 e 313-325). 
fora do verdadeiro estado social e, em razão dessa inferioridade civilizacional, permaneceram classificados como incapazes de governarem a si próprios na legislação de 1798. Por isso mesmo, tal como outros grupos e indivíduos considerados relativamente incapazes, foi-lhes reservado o privilégio de órfãos. De acordo com tal perspectiva, quando descidos dos sertões, poderiam ser contratados por particulares que, em contrapartida, deveriam pagar-lhes salários e cuidar de sua educação, catequese e "civilização" (Cunha, 1992b, p. 147).

A carta régia de 1798 não teve efeito prático em todo o mundo colonial, pois o Diretório continuou operando oficiosamente em diferentes partes da América portuguesa (Cunha, 1992b, p. 138). No caso da capitania do Espírito Santo, a nova lei entrou em vigor e, em 1806, quando o novo governador recriou o cargo de diretor de índios na capitania, houve protestos contra o ato. Ao que tudo indica, a partir de então, a jurisdição do diretor de índios ficou adstrita aos índios botocudos, que estavam sendo conquistados e descidos dos sertões, e aos índios da capitania enquanto estivessem em serviço obrigatório fora de suas vilas de origem (Moreira, 2010, p. 225).

\section{Povo e população nas villas de índios}

Ao longo da permanência da Companhia de Jesus na capitania do Espírito Santo, os missionários construíram várias obras de importância e, entre os 10 aldeamentos mencionados na documentação da ordem, duas missões se destacaram e tiveram longa duração: Nossa Senhora da Assunção de Reritiba e Santo Inácio e Reis Magos, ambas fundadas no século XVI e bastante populosas ao longo do período colonial (Leite, 2006, p. 231). Trinta anos depois da expulsão dos jesuítas pelo marquês de Pombal, em 17591760, ainda era visível o relativo sucesso da obra missionária no Espírito Santo; pois, em 1790, o capitão-mor Inácio João Mongeardino informava ao governador da Bahia que, entre as cinco vilas existentes na capitania, duas eram vilas de índios, e ambas só eram menos populosas que a vila de Vitória, que funcionava como cabeça de comarca e capital. Eram elas: Nova Benavente e Nova Almeida, respectivamente as antigas missões de Reritiba e dos Reis Magos, ambas elevadas a vila em 1760, logo depois da expulsão dos padres. ${ }^{7}$

Na memória estatística de Mongeardino, a população da capitania foi classificada e dividida em três extratos distintos: "índios" (5.729 pessoas), "livres" (4.930 pessoas) e "escravos" (6.834 pessoas). Foram ainda citadas 200 pessoas não qualificadas em termos de condição civil (livres e escravos) ou segundo a ancestralidade real ou presumida, isto é, pelo "sangue", tal como os "índios" foram classificados. ${ }^{8}$ Somando-se todos, chegou-se

\footnotetext{
${ }^{7}$ Officio do capitão-mór do Espirito Santo Ignacio João Mongeardino para o governador da Bahia, em que Ihe participa a remessa da seguinte informação. Villa da Victoria, 11 de julho de 1790. In: Brasil. Projeto Resgate Barão do Rio Branco. Catálogo Eduardo de Castro Almeida, doc. 13.859-13.875.

${ }^{8}$ Sobre o conceito de "sangue" e "casta" no mundo colonial, ver Schwartz e Salomon (1999, p. 444).
} 
a uma população de 17.693 indivíduos, embora o próprio Mongeardino tenha asseverado que a população total da capitania fosse de “[...] 22.493 para muito mais e não para menos". ${ }^{9}$

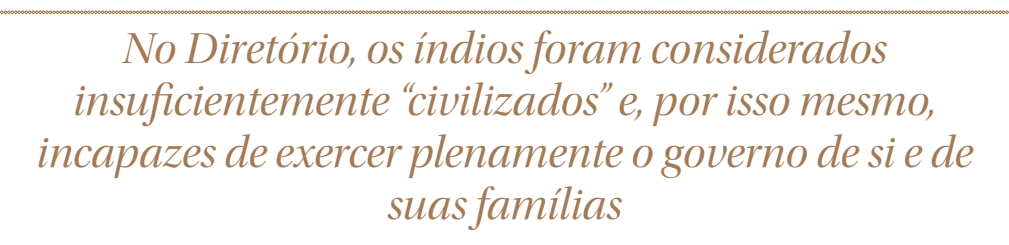

Mais que números precisos, a estatística de Mongeardino é importante porque ilustra, de maneira vívida, as categorias fundamentais que organizavam a vida e as hierarquias sociais locais. Desse ponto de vista, a sociedade colonial do Espírito Santo estava dividida e hierarquizada em três condições jurídicas fundamentais: livres, índios e escravos. É válido salientar, portanto, que a palavra índio não servia apenas para indicar que certas pessoas e coletividades tinham ancestralidade e consanguinidade com os povos nativos da América. Funcionava, também, como uma poderosa categoria jurídica, estabelecendo os direitos e as obrigações dos grupos e das pessoas assim qualificados, que estavam bem detalhados na lei. Em termos concretos, os índios, embora fossem homens e mulheres livres, representavam um segmento distinto, numeroso e com funções específicas no quadro da sociedade local, não se confundindo nem com os escravizados africanos ou afrodescendentes e tampouco com os setores considerados livres (portugueses, brancos, pardos, mestiços etc.). Além disso, toda a população indígena da capitania concentrava-se em duas vilas: Nova Benavente, com 3.017 índios e 102 escravos; e Nova Almeida, com 2.712 índios e 42 escravos. ${ }^{10}$

Mongeardino definiu os índios como "gente inteiramente preguiçosa”, pois não estimavam as riquezas e menos ainda trabalhavam para conquistá-las e acumulá-las, "[...] de sorte que possuindo com que passarem alguns dias, não cuidam do futuro e só obrigados da necessidade ou temor trabalhão". ${ }^{11}$ A exemplo de outras elites coloniais, não escondia seu vivaz desprezo pelos índios e, certamente, preferiria vê-los distribuídos por terras, negócios e casas dos moradores, prestando trabalho de forma mais assídua e controlada. A despeito disso, os índios de Nova Almeida e Nova Benavente continuariam livres e vivendo em terras coletivas próprias, asseguradas por cartas de sesmarias, confirmadas por d. José na época de criação das vilas, e prestando o trabalho obrigatório ao rei e aos moradores.

Na memória de Mongeardino ainda encontramos outra importante informação: em ambas as vilas os índios eram governados por seus "chefes" e, àquela

${ }^{9}$ Brasil. Projeto Resgate Barão do Rio Branco. Catálogo Eduardo de Castro Almeida, doc. 13.859-13.875.

${ }^{10}$ Ibidem.

${ }^{11}$ Ibidem. 
altura, isso significava que estavam desempenhando há 30 anos as funções de vereadores, juízes, procuradores e também ocupando postos nas ordenanças locais. Desse ponto de vista, os índios eram não apenas a esmagadora maioria da população das vilas de Nova Almeida e Nova Benavente, mas também de seu povo. Vale frisar que povo e população não são termos intercambiáveis quando se escreve a história política colonial, pois faltam à palavra população o conteúdo e o significado político que existe na palavra povo. Povo era aquela parcela da população livre que tinha direitos políticos e podia participar da governação de suas próprias vilas e municípios (Godinho, 1977, p. 74). Na qualidade de "homens bons", o povo exercia o foro de cidadão, pois, como esclarece Maria Fernanda Bicalho:

A ocupação de cargos na administração municipal constituía-se na principal via de exercício da cidadania no Antigo Regime português. Para Vitorino Magalhães Godinho, este exercício ligavase à noção de comunidade política, ou seja, à noção de comunidade tal como existia à escala municipal, pois as vilas e as cidades constituíam-se na primeira "pessoa coletiva", surgindo, portanto, no âmbito das municipalidades, a noção de cidadão. Os cidadãos eram os responsáveis pela res publica, que, traduzida como coisa pública, se articulava ao governo da comunidade. Cidadãos eram, em suma, aqueles que, por eleições de seus pares, desempenhavam ou haviam desempenhado cargos administrativos nas câmaras, bem como seus descendentes. (Bicalho, 2003a, p. 144)

A maior parte da documentação acerca das vilas de índios do Espírito Santo se perdeu, sendo Nova Almeida mais bem documentada que Nova Benavente. ${ }^{12}$ Mas ambas foram criadas pelo mesmo ouvidor, Francisco Salles Ribeiro, na mesma época e segundo iguais critérios e procedimentos, demarcando-se terras coletivas para os índios e seus descendentes, instituindo-se os oficiais da câmara pelo voto do povo e dando preferência aos índios na ocupação dos cargos da justiça, guerra e ordenanças. Para mensurar o significado político de tais eventos, convém lembrar o que Cláudia Damasceno Fonseca salientou, isto é, o "paralelismo existente entre as hierarquias urbanas e a estrutura social do Antigo Regime" português, pois os termos "vila" e "cidade" faziam parte do sistema de concessão de títulos, privilégios e funções que enobreciam as localidades e seus moradores (Fonseca, 2003, p. 43). Mais ainda, enquanto muitos povoados importantes pleiteavam o título e os privilégios de vila e tinham suas solicitações negadas pela Coroa, a exemplo dos arraiais do Tejuco, de Santa Luzia e de Santa Bárbara, em Minas Gerais (Fonseca, 2012, p. 86), os índios da América portuguesa tiveram suas aldeias elevadas à condição de vila, e seus moradores índios, agraciados com o privilégio de participar da governança local.

\footnotetext{
12 Sobre Nova Almeida, há dois importantes documentos que testemunham seu funcionamento como uma vila de índios: o Livro tombo da vila de Nova Almeida (op. cit.) e o manuscrito "Notícia histórica da vila de Nova Almeida na província do Espírito Santo", em que o autor copiou várias atas e extratos de atas do período colonial, anexando-as ao final de sua reflexão. Arquivo Nacional do Rio de Janeiro (ANRJ). Coleção de memórias e outros documentos sobre vários objetos. SDH, códice 807, v. 19.
} 
Na capitania do Espírito Santo, o ouvidor Francisco Salles Ribeiro recebeu todo o apoio do reino e do governo da Bahia para erigir vilas nos aldeamentos de Reritiba e Reis Magos. D. José, por exemplo, autorizou despesas para a aquisição de varas pintadas para os juízes, vereadores, procuradores e outros oficiais da câmara e para a compra de livros para registrar as atividades da câmara e do escrivão. Além disso, mandou que fossem dadas a cada vila cópias das Ordenações do Reino. Nos livros destinados à câmara, dever-se-ia reservar um para seus atos; outro para receitas e despesas; outro para ordens; e, finalmente, um para audiência geral e provimento dos ouvidores. Para o escrivão, autorizaram-se dois livros para registrar "querelas" e "sumários" e um terceiro para servir de livro de notas. ${ }^{13}$ Pouco depois, chegou ao Espírito Santo uma sumaca, vinda da Bahia, trazendo 14 livros em branco e dois jogos das Ordenações do Reino para serem distribuídos igualmente entre as duas aldeias de índios que seriam transformadas em vilas. ${ }^{14}$

Em Nova Almeida, o monarca mandou demarcar a sesmaria dos índios “[...] até os confins das terras de que presentemente se acham de posse dos Indios, as quais medireis e demarcareis com os práticos que elegeres, para que as fiquem por ora possuindo em Commum os mesmos Indios [...]". ${ }^{15}$ No termo de conclusão de medição das terras dos índios, consta que foram demarcados, em domínio comum, para uso dos índios da vila Nova de Almeida e seus descendentes:

[...] todas as terras de que actualmente estão de posse e que se comprehendem dentro dos ditos Marcos, e rumos do Norte e Sul pela Costa do Mar que são nove léguas novecentos e seis braças e meia e seis léguas para o Sertão, correndo rumo Leste Oeste, com declaração que os ditos índios não serão perturbados em suas posses sem ordem de sua Magestade [...]. ${ }^{16}$

Além disso, em 1760, a câmara da vila de Nova Almeida foi eleita e constituída, dando-se preferência aos índios, sendo eleitos a votos do povo: um de seus moradores para juiz, que acumularia também a função de juiz dos órfãos; três vereadores; e um procurador do conselho, todos índios considerados habilitados para tais funções. Ficaram estabelecidos mandatos de três anos e, nas eleições vindouras, recomendava-se seguir as instruções da Ordenação Livro $1^{\circ}$, título 67, guardando-se em tudo as formalidades. ${ }^{17}$ Em ambas as vilas, o escrivão da câmara acumulava o cargo de diretor de índios, conforme o parecer do

\footnotetext{
${ }^{13}$ Registro das despesas com as aldêas dos Reis magos e Iritiba que sua Magestade Fidelíssima manda erigir em Villa. In: Espírito Santo. Livro tombo da vila de Nova Almeida, 1945. p. 29.

${ }^{14}$ Registro da carta de vinte seis de março de mil setecentos e cincoenta e nove do senhor conde d. Marcos de Noronha, vice-rei do Estado. In: Ibidem, p. 28.

${ }^{15}$ Registro de ordens porque S. Magestade Fidelíssima manda erigir em vila com o nome de Villa de Nova Almeida esta Aldeia dos Reis Magos. In: Ibidem, p. 12.

16 Sentença. In: Ibidem, p. 43.

17 Registro de ordens porque S. Magestade Fidelíssima manda erigir em vila com o nome de Villa de Nova Almeida esta Aldeia dos Reis Magos. In: Ibidem, p. 12.
} 
Conselho Ultramarino, sobre a aplicação e adaptação do Diretório aos índios do Estado do Brasil. ${ }^{18}$

Inicialmente, os índios de Nova Benavente e Nova Almeida exerceram a maioria dos cargos da república. Mas, à medida que os "portugueses" ("pardos" e "brancos") aforavam suas terras, tornando-se seus vizinhos, e parte deles também seus parentes em razão dos casamentos mistos, passaram a repartir com eles o poder político local. ${ }^{19} \mathrm{Em} 1812$, isto é, meio século depois da fundação das duas vilas, os índios permaneciam um grupo étnico, jurídico e social distinto na sociedade colonial regional e exerciam a cidadania típica do Antigo Regime adaptado aos trópicos. Em Nova Benavente, dividiam meio a meio o poder com os "portugueses"; enquanto em Nova Almeida, distrito que a essa altura tinha oficialmente mais de 3 mil índios, sem contar os "brancos" e "pretos", todos os vereadores e juízes continuavam sendo índios, fazendo da vila uma grande república de índios em plena atividade nas primeiras décadas do século XIX (Moreira, 2012, p. 236).

\section{Ressocialização, "reformas dos costumes" e novas identidades indígenas}

É difícil aquilatar o quanto a diversidade étnica dos índios aldeados no Espírito Santo condicionou sua organização social nas terras que possuíam coletivamente na capitania. Mas, a exemplo de outras partes da América portuguesa, os aldeamentos formados pelos jesuítas no Espírito Santo territorializaram, em diferentes momentos e circunstâncias, povos e linhagens diversas: tupiniquins, temiminós, aimorés, pataxós e mares verdes são alguns dos nomes e etnônimos citados na documentação da ordem para se referir à variada origem étnica da população aldeada (Leite, 2006).

Depois da expulsão dos jesuítas e com o desaparecimento dos livros das câmaras de Nova Almeida e Nova Benavente, faltam informações consistentes sobre os descimentos voluntários e forçados de novas famílias, linhagens e povos para ambas as vilas. O mais plausível é que as vilas, bem como os engenhos e fazendas da capitania, continuaram agregando parte da numerosa população de índios puris, coroados, botocudos, maxacalis, entre outros, que viviam nos sertões anexos da capitania, mencionados frequentemente nas fontes dos séculos XVIII e XIX. Até mesmo índios aldeados em outras capitanias migraram para o Espírito Santo, como aconteceu em 1772, quando muitos índios fugiram das vilas de Caravelas e Alcobaça, certamente por avaliarem que a vida na capitania era superior à que dispunham em Porto Seguro. ${ }^{20}$

\footnotetext{
${ }_{18}$ Parecer do Conselho Ultramarino da Bahia sobre os paragraphos do Directorio para regimen dos Indios das Aldeias das capitanias do Pará e Maranhão, approvados por Alvará régio de 17 de agosto de 1758 e que podiam ser applicaveis aos Indios do Estado do Brazil. In: Brasil. Projeto Resgate Barão do Rio Branco. Catálogo Eduardo de Castro Almeida, doc. 4.256

19 Em relação aos casamentos mistos e seus impactos na organização social e política local, ver Moreira (2015).

${ }^{20}$ Registro do edital do doutor ouvidor geral e corregedor dessa comarca, José Ribeiro Guimarães de Athayde. In: Espírito Santo. Livro tombo da vila de Nova Almeida, 1945. p. 99.
} 
Nas vilas de Nova Benavente e Nova Almeida, os índios viviam divididos em diferentes lugares, segundo laços de parentesco, afinidades e relações de vizinhança, organizados em povoados. Em Nova Almeida, a comunidade mais conhecida e numerosa era a que vivia na freguesia, onde se localizava a câmara, a igreja e um conjunto de casas, distribuídas no entorno da praça principal quadrada, que levava o nome da própria vila. Mas existiam outros povoados: Aldeia Velha, Piriquiaçu (ou Destacamento), distrito das Águas, Riacho, Regência, Iapara, Samanha, Tambira, entre outros esporadicamente mencionados nas dispersas fontes e informações sobre a vila.

\section{Trinta anos depois da expulsão dos jesuitas pelo marquês de Pombal, em 1759-1760, ainda era visível o relativo sucesso da obra missionária no Espírito Santo}

Todos os povoados ficavam subordinados à jurisdição política do governo da vila, e a maior parte deles tinha seus respectivos capitães. Acima deles figurava o capitão-mor da vila e, segundo informações coevas, esse cargo foi habitualmente ocupado por um principal indígena, responsável, entre outras funções, por captar, organizar e distribuir os índios para prestar o serviço obrigatório para o rei e os moradores. No começo da década de 1830, pouco antes de serem abolidos os corpos de ordenanças pelo novo regime político brasileiro, ainda era um capitão-mor indígena que arregimentava a força de trabalho dos índios (Moreira, 2010, p. 29); e, em 1860, embora não existisse mais oficialmente o posto de capitão-mor, o líder principal dos índios ainda era chamado por essa patente e continuava representando politicamente os índios, pois, entre as autoridades que recepcionaram d. Pedro II na visita oficial que fez à vila, constou um séquito de índios, liderado por seu capitão-mor (Rocha, 2008, p. 257).

Do ponto de vista interno, portanto, os índios não formavam um grupo social homogêneo; mas, do ângulo da sociedade colonial, eram localmente reconhecidos e se reconheciam como um grupo social específico em termos de obrigações e privilégios. Assim, na qualidade de índios da vila de Nova Almeida, eram todos mais ou menos conectados em uma experiência social comum e conscientes do lugar social e jurídico que ocupavam na região, como índios cristãos, vassalos da monarquia e moradores da vila. Quarenta anos depois da fundação da vila de Nova Almeida, em um ofício endereçado ao governador da Bahia, de 1804, o ouvidor da comarca do Espírito Santo relatou o estado de "civilização" em que se encontravam os índios de sua jurisdição, deixando algumas informações importantes sobre eles:

Os progressos da civilisação dos Indios desta comarca sobre que V. Ex. me manda informar me persuado ter algum aumento, porquanto ainda que a maior parte conserva a estúpida indolencia do desprezo de adquirir bens e conserval-os, como por herança 
de seus pais e avós; comtudo ella ja não he tanta, que não trabalhem para comer e vestir, imitando os brancos no modo do vestido: e entre os mesmos Indios já aprecem alguns que se não distinguem na civilidade daquelles, como de proximo encontrei hum Juiz em Villa Nova de Almeida, que até me acompanhou a cavalo com decência até ao fim de seu distrito, de sorte que he de esperar que aquella ambição louvavel, que falta na maior parte, cresça e se vá espalhando entre os outros, se não se desprezarem os meios de a facilitar. ${ }^{21}$

Medindo o estado de "civilização" dos índios pela métrica dos valores metropolitanos e colonialistas, o ouvidor não capturou os índios segundo seus próprios termos e valores. Para ele, a maior parte mantinha o costume ancestral de valorizar pouco a acumulação, enquanto outros, a exemplo do juiz indígena de Nova Almeida, não diferia nos trajes e na civilidade dos demais brancos ou portugueses que conhecia. Isso sugere que existiam diferenças internas importantes entre os índios da vila, não somente aquelas relativas aos costumes, idiomas e valores de seus antepassados, mas também em termos de distinção social no mundo colonial, sendo alguns mais abastados e adaptados culturalmente que outros e também mais capazes de ocupar lugares de prestígio na sociedade local. Além disso, vale registrar que a diferenciação social e a imposição das hierarquias típicas da sociedade estamental entre os índios foram objetivos manifestos das reformas pombalinas, que apostaram na eficiência da concessão de trajes especiais e privilégios aos índios que ocupassem os cargos da república para acelerar esse processo (Lopes, 2005, p. 98; Sommer, 2014, p. 113).

A reforma dos costumes era exigida no Diretório, estava em curso e foi assunto discutido na câmara da vila de Nova Almeida em uma das ocasiões em que os oficiais índios estiveram reunidos com o ouvidor da comarca do Espírito Santo. Nessa reunião, as mulheres foram descritas como apegadas às tradições de seus ancestrais: preferiam arrumar o cabelo em duas tranças, em vez de uma só, tal como vigorava na moda portuguesa; e nisso pareciam estar apegadas ao "primitivo paganismo". Sentavam-se na igreja "com os pez e pernas estendidos para diante indecentemente, e contra o devido recato e honestidade". Insistiam em vestir "huma camisa comprida, sem outro algum vestido que as orne e alinhe com a devida compostura"; e continuavam a falar a língua materna, "com total ignorancia da portuguesa, cuja Vassalagem profeção". Em razão disso, tornaram-se o alvo preferencial da reforma dos costumes, pois foi concluído naquela reunião que as mulheres levavam uma vida oposta "à nobreza dos costumes em que devião florescer", determinando-se

${ }^{21}$ Officio do ouvidor da comarca do Espírito Santo Manuel José Baptista Felgueiras para o governador da Bahia, no qual informa acerca do estado de civilisação em que se encontra os índios de sua comarca. In: Brasil. Projeto Resgate Barão do Rio Branco. Catálogo Eduardo de Castro Almeida, doc. 26.326. 
"de commum acordo" penas de prisão, castigo físico e corte sumário dos cabelos das mulheres infratoras das novas deliberações. ${ }^{22}$

Subjacente à reforma dos costumes, afigurava-se também uma estratégia para compelir as famílias e/ou os indivíduos a prestarem trabalho aos moradores, em troca de jornal, e a ingressarem na economia mercantil. Afinal, obrigar as mulheres acima de 6 anos de idade a vestir-se e a instruir-se minimamente na língua e na cultura dominante, sob pena de vê-las publicamente humilhadas, presas e espancadas, representava um custo econômico e certamente não desprezível para elas e suas famílias. Além disso, só existia a chamada reforma dos costumes porque os índios mantinham costumes e valores diversos dos dominantes.

Em Nova Almeida, por exemplo, os índios gostavam de festas e realizavam-nas respeitando o calendário católico, empenhando-se, especialmente, nas festas dos santos de suas principais devoções. Na festa de Todos os Santos, comemorada em 1818 tanto em Nova Almeida como em Piriquiaçu, a festa era católica, mas o modo de prepará-la e desfrutá-la era indígena, pois regada por cauim confeccionado coletivamente, segundo os costumes dos ancestrais (Saint-Hilaire, 1974, p. 104). Além disso, uma mesma comunidade, ou até um único indivíduo, a exemplo do índio juiz encontrado pelo ouvidor Felgueiras e por ele considerado bastante português e civilizado nos modos sociais, nos trajes e no linguajar, poderia ser também muito semelhante a seus pares considerados mais "atrasados", "primitivos", "rústicos", "silvestres" ou "selvagens" se encontrado em outros lugares e circunstâncias, como no mato caçando e pescando - nu ou com pouca roupa — ou em uma festa regada por cauim.

Hibridismo, transculturação, mestiçagens culturais e etnogênese são alguns dos conceitos talhados pela história, antropologia e etno-história para dar conta desse complexo processo histórico-social que fazia emergir novas comunidades, culturas e identidades indígenas no mundo colonial (Vainfas, 1995; Schwartz e Salomon, 1999; Hill, 1996; Boccara, 2001; Gruzinski, 2001; Almeida, 2003; Bartolomé, 2006). Em outras palavras, as reformas dos costumes e as pressões colonialistas geravam transformações importantes entre os indígenas territorializados. Mas as fronteiras étnicas entre índios e não índios continuavam sendo reproduzidas em novos termos. Por exemplo, Saint-Hilaire passou pela vila de Nova Almeida em 1818 e registrou que os índios da costa, especialmente os de São Pedro, Nova Benavente e Nova Almeida, tinham mais "facilidade de imaginação que os luso-brasileiros desta mesma parte da América, [...] demonstram menos tristezas e têm mais vivacidade nas respostas" (Saint-Hilaire, 1974, p. 71). E completou:

Entretanto, essas qualidades não lhes servem para o futuro; eles pertencem por inteiro ao presente e o que ganham gastam no mesmo instante; bebem, amam e, logo que nada mais têm,

${ }^{22}$ Cf. Mercier, José Maria. Relatório, ou Notícia histórica da vila de Nova Almeida, na província do Espírito Santo. In: ANRJ. Coleção de memórias e outros documentos sobre vários objetos. SDH, códice 807, v. 19, apêndice 2 . 
sofrem a fome sem proferir um lamento. Mostram-se tão cheios de paciência, tão tranquilos quanto desleixados e pode mesmo ser que as duas primeiras qualidades não passem do resultado da última. (Saint-Hilaire, 1974, p. 71)

Viver o presente e no presente; ser tranquilo e paciente; amar, comer e beber e não reclamar da fome quando ela se afigura como tal foram interpretados por Saint-Hilaire em duas chaves diversas: como virtudes e como consequências secundárias de um vício primário, isto é, o do desleixo ou da imprevidência com relação ao futuro. Mas quer como virtude, quer como vício, essas características foram transformadas em sinais diacríticos que diferenciavam os índios dos não índios na sociedade colonial. Vale notar, contudo, que as tão criticadas imprevidência e "preguiça" dos índios tinham uma base de sustentação bastante objetiva: suas terras coletivas, onde podiam, com relativa autonomia, viver e trabalhar para si mesmos e suas famílias em vez de trabalhar e viver em terras alheias e a serviço unicamente dos interesses dos portugueses. Além disso, para defender suas terras eles frequentemente acionaram as novas identidades políticas construídas no mundo colonial, apresentando-se como "índios cristãos" e "vassalos", que cumpriam fielmente o serviço (obrigatório) do rei e, mais ainda, como o "povo" de suas vilas e povoações.

\section{"Voz do povo" e política indígena}

A importância política das câmaras para o império português foi salientada por Boxer; pois, juntamente com as irmandades de caridade, os conselhos municipais ajudavam a manter as diferentes colônias unidas ao reino. Ainda segundo Boxer, os homens que acediam aos postos de ambas as instituições, além de serem basicamente do mesmo extrato social, podem ser considerados representativos das elites coloniais (Boxer, 1981, p. 267).

Mais recentemente, a mesma percepção tem sido reforçada, pondo-se em relevo que a relação entre centro e periferia foi equacionada, no âmbito colonial, por um processo de municipalização do espaço político da América portuguesa. Nesse cenário, as câmaras representavam uma instituição fundamental, mediando as relações políticas entre as elites coloniais e a Coroa. Também tem sido frisado seu papel em âmbito local, como espaço político para a resolução de questões econômicas e sociais dos moradores (Bicalho, 2003b, p. 352; Monteiro, 2010). Finalmente, também vale destacar que, para as elites coloniais, o controle sobre as câmaras de suas respectivas localidades era uma oportunidade de construir redes de parentesco e clientela, baseadas na apropriação, divisão e distribuição dos recursos provenientes da administração municipal (Fragoso, 2003, p. 15; Hespanha, 2010b, p. 70).

Em repúblicas de índios ou de maioria indígena, no entanto, a questão do poder local ganhou uma dimensionalidade própria tanto com relação ao papel das câmaras na governança de interesses econômicos e sociais locais quanto com relação a seu papel de instituição de mediação entre índios e 
poder metropolitano. Os índios estavam subordinados aos diretores, grassava sobre eles enorme preconceito e, naturalmente, tais circunstâncias especiais podiam gerar impactos restritivos à sua efetiva participação política. Henry Koster, por exemplo, viajando pelo Ceará em fins de 1810, considerou risível a participação dos índios na governança local, supondo de maneira firme que o exercício de funções políticas por eles não passava de um artifício para enganá-los e iludi-los:

Cada aldeia possui dois Juízes Ordinários, com função anual. Um juiz é branco e o outro indígena, e é lógico supor que o primeiro tem, realmente, o comando. [...] Os indígenas têm também seus Capitães-Mores cujo título é vitalício e dá algum poder sobre seus companheiros, mas como não há salário, o Capitão-Mor indígena é muito ridicularizado pelos brancos e, com efeito, um oficial meio nu, com sua bengala de castão de ouro na mão é um personagem que desperta o riso aos nervos mais rijos. (Koster, 2002, p. 224-225)

\section{Na festa de Todos os Santos, comemorada em 1818 tanto em Nova Almeida como em Piriquiaçu, a festa era católica, mas o modo de prepará-la e desfrutá-la era indígena}

Nas vilas de índios da capitania do Espírito Santo, o funcionamento das câmaras esteve fundamentalmente voltado para fazer valer as diretrizes gerais do Diretório pombalino, procurando principalmente garantir um sistema eficiente de sujeição dos índios ao trabalho e a "reforma" de seus costumes. Desse ponto de vista, sofre-se a tentação de concordar com Koster e ver a propalada equiparação política dos índios aos portugueses mais como um engodo que como um exercício de autogoverno, ainda que parcialmente tutelado. Mas isso representa apenas um dos ângulos da questão, pois é por meio do protagonismo dos índios que se pode investigar e aquilatar o significado de sua participação política nas câmaras de suas respectivas vilas. Nesse período, além disso, o protagonismo dos índios moradores em vilas, freguesias e lugares tornou-se particularmente ativo e visível em questões que envolviam suas terras coletivas.

O Diretório autorizava e incentivava os aforamentos de terras indígenas e também vedava expressamente que os índios fossem prejudicados e perturbados em seus sítios. Mas não esclarecia quem, no final das contas, era efetivamente responsável por isso. ${ }^{23}$ As condições dos aforamentos, em termos de tempo,

${ }^{23}$ Manuela Carneiro da Cunha (1992a, p. 24) salientou, por exemplo, que a tutela é um tema jurídico "obscuro" e cheio de "quiprocós", advertindo sobre a necessidade de diferenciar a tutela que incidia sobre a pessoa daquela exercida sobre o patrimônio dos índios. 
valor, área etc., não eram determinadas pelo texto do Diretório, tampouco o destino que se devia dar aos rendimentos dos foros. Em razão disso, a lei permitia uma boa margem de manobra para negociar localmente procedimentos e valores, que podiam variar bastante de uma capitania para outra.

Nas vilas de Nova Benavente e Nova Almeida, as terras demarcadas para os índios, isto é, suas sesmarias, coincidiam com o termo da vila, tendo sido apenas reservada uma parcela para os párocos. ${ }^{24}$ Além dessa sobreposição, a documentação atesta que as câmaras de ambas as vilas foram instituições particularmente importantes para os índios, pois o poder local controlou, juntamente com o ouvidor da comarca, a gestão do patrimônio territorial coletivo dos índios. Os ouvidores autorizavam e até mesmo sugeriam os aforamentos, mas a validação e aprovação final passavam pelo crivo das câmaras, onde os contratos, os valores e as condições dos aforamentos eram registrados em livro próprio para esse fim (Moreira, 2013, p. 280). O modelo de gestão do patrimônio territorial dos índios ficou, portanto, bastante próximo do utilizado no reino para gerir terras e logradouros de uso comum, que eram, de acordo com Vitorino Magalhães Godinho, administrados e repartidos pelas municipalidades (Godinho, 1977, p. 96). Enquanto os índios ocuparam a maior parte dos cargos de suas repúblicas, esse modelo não gerou conflitos. Mas quando passaram a repartir com os portugueses pardos e brancos o poder local, os conflitos por terra começaram em ambas as vilas, e as "terras pertencentes aos índios" começaram a ser nominados nos contratos de aforamento como "terras pertencentes à câmara" (Moreira, 2013, p. 282).

Os primeiros conflitos de terra envolvendo índios coloniais e portugueses na capitania datam da década de 1790 e aconteceram na vila indígena de Nova Benavente. O pomo da discórdia eram os aforamentos permitidos e incentivados pelo Diretório e alguns esbulhos e usurpações que estavam em curso. O conflito tomou foro público quando um grupo de moradores do lugar conhecido como Iryry (ou Iriri), todos eles índios, sentiu-se lesado com o que andavam fazendo certos portugueses, tanto pardos quanto brancos, contra seus direitos de posse e domínio sobre suas terras confirmadas no governo de d. José. Imbuídos do desejo de defender seus modos de viver, seus valores e o que entendiam ser seus direitos e a verdade, acionaram, de início, o poder local, quando, em agosto de 1795, 15 deles apresentaram um requerimento à câmara da vila de Nova Benavente. Nesse documento, denunciaram a invasão de suas terras por um homem chamado José da Silva Pereira, que, "sem títulos", isto é, sem contrato de aforamento, fincava marcos nas terras dos índios, impedindo-os de ter agricultura e plantações para sustentarem a si e às suas mulheres e filhos (Moreira, 2013). ${ }^{25}$

${ }^{24}$ Registro de ordens porque S. Magestade Fidelíssima manda erigir em vila com o nome de villa de Nova Almeida esta aldeia dos Reis Magos. In: Espírito Santo. Livro tombo da vila de Nova Almeida, 1945. p. 13.

${ }^{25}$ A contenda entre índios e "portugueses" na vila de Nova Benavente pode ser pesquisada em vários documentos, todos anexados a um ofício expedido por d. Fernando José de Portugal ao ministro d. Rodrigo de Souza Coutinho. Cf. Arquivo Histórico Ultramarino (AHU). ACL. CU 005-O1. Cx. 93, doc. 18.206-18.227. 
Pouco tempo depois, em 21 de agosto de 1795, o corregedor da comarca do Espírito Santo e conservador dos índios, José Pinto Ribeiro, despachava ao escrivão-diretor dos índios, recomendando-lhe que verificasse com o juiz de medição de terras a situação dos índios, reafirmando que só podiam ser aforadas as terras "totalmente devolutas" para que estes não fossem prejudicados em suas posses e seu domínio. Por questões não explicitadas na documentação, o mesmo corregedor suspendeu o despacho dado anteriormente. Isso talvez explique por que os índios tenham resolvido ir mais fundo na defesa de seus direitos e recorrer à "Soberana Rainha”, imprimindo à questão contornos políticos e jurídicos mais largos e expressivos.

Em 17 de setembro de 1795, três índios da vila de Nova Benavente encabeçaram e assinaram um requerimento à rainha d. Maria I, subscrito por outros 40 índios moradores da mesma vila. Desses três índios, dois eram oficiais da câmara e exerciam, àquela altura, os cargos de vereador e juiz ordinário. No documento, pediam que ela pusesse seus olhos sobre os "Índios", seus "pobres vassalos", e, como "mãe comum", “distribuísse justiça”, listando o nome e o sobrenome de 40 "queixosos", todos homens indígenas moradores da vila, a maior parte deles casados. Ainda esclareciam que muitos outros índios não eram nomeados "por morarem muito distantes", mas eles "se prostram também como voz do Povo [...]".26

A "voz do povo" de Benavente era uma voz indígena; e, na qualidade de índios cristãos e vassalos, denunciaram abusos e arbitrariedades cometidas contra eles e suas famílias, perpetradas por moradores e autoridades, e pediam justiça:

E todos os que aqui presentes por nossos nomes, nos pomos aos venerandos e Reais Pés de Vossa Majestade, pedindo nos ampare e patrocine, e nos dê o seu Real auxílio; que não possam os Portugueses nos tomar as nossas terras, e nem os Magistrados da Comarca da Capitania mandar que se lhas entregue aos Portugueses $[\ldots] .{ }^{27}$

O poder local jogou um papel importante na vida dos índios de Nova Benavente não muito diferente do que jogava em outras partes do império português. Sua participação nessa instância de governo permitiu que negociassem com os ouvidores quem poderia entrar em suas terras e em quais condições. E, ao que tudo indica, esse arranjo político funcionou bastante bem até a eclosão dos primeiros conflitos territoriais, em 1795. Além disso, quando os conflitos tomaram proporções tais que, de fato, começaram a prejudicar efetivamente a territorialidade dos índios, foi ainda por intermédio de seus representantes na câmara que eles conseguiram ter acesso à rainha e peticionar por justiça. Assim, três anos depois, ordens expressas vindas da rainha mandavam que os fatos fossem apurados, e os índios, respeitados. ${ }^{28}$

${ }^{26}$ AHU. ACL. CU 005-O1. CX. 93, doc. 18.226

${ }^{27}$ AHU. ACL. CU 005-01. Cx. 93, doc. 18.226.

${ }^{28}$ AHU. ACL. CU 005-O1. CX. 93, doc. 18.206. 
A importância do poder local para os índios, especialmente no que tange à conservação de suas terras coletivas, é confirmada pelo processo histórico-social da vila de Nova Almeida. Afinal, 50 anos depois dos conflitos entre índios e portugueses em Nova Benavente, a câmara de Nova Almeida também começou a ser controlada por não índios, os aforamentos e esbulhos de terras aumentaram e, em razão disso, também surgiram acirrados conflitos entre índios e não índios na vila de Nova Almeida (Moreira, 2002). Do ângulo da longa duração, portanto, a participação dos índios na governança de suas vilas não conseguiu impedir o crescente esbulho territorial e tampouco retirou-os de sua condição subalterna. Contudo, dificultou bastante a dilapidação territorial em curso e, certamente, também a retardou ao fornecer instrumentos políticos e jurídicos de luta e resistência.

\section{Cidanização, cidadania e descidanização dos índios: considerações finais}

As reformas pombalinas esmeraram-se na tentativa de impor aos índios uma vida "civil" e "civilizada", renovando seus direitos territoriais de posse e domínio - onde deveriam desenvolver comércio, agricultura e pagar dízimos - e concedendo-lhes direitos políticos em suas vilas e povoações. Pelas "paternais" providências do príncipe, foi concedida aos índios a cidadania típica do Antigo Regime, adaptando-a ao mundo colonial e às necessidades de exploração da força de trabalho dos índios, graças à implementação do Diretório pombalino.

O processo de "cidanização" controlada foi bem aproveitado pelos índios de Nova Benavente, quando surgiram os primeiros conflitos de terras entre eles e os portugueses. Em um movimento próprio, começaram a mobilizar os recursos políticos, ideológicos e institucionais da monarquia portuguesa para fazer valer seus interesses e agendas. Peticionaram, primeiramente, aos oficiais da câmara de sua vila; depois à rainha; e, em ambas as vezes, fizeram isso na qualidade de povo, vassalos e índios cristãos.

O interesse mais crucial dos índios era proteger suas terras, pois, sem terra própria, a propalada liberdade poderia transformar-se em peça de ficção. A despeito do trabalho obrigatório e da ingerência de diretores e de outras autoridades coloniais na vida política e social de ambas as vilas, os índios de Nova Benavente e Nova Almeida conseguiram manter uma importante zona de autonomia em suas terras coletivas: plantavam, caçavam, pescavam, faziam festas, formavam famílias e gozavam a vida com seus amigos, filhos e parentes sem se preocupar em acumular riquezas para o dia de amanhã. Para defender suas terras e seu modo de vida, mobilizavam costumes e tradições ancestrais e também uma gama variada de costumes, instituições e regras aprendidos no mundo colonial, reelaborados e postos a serviço de seus próprios interesses e agendas. Entre esses recursos, destacou-se a utilização do poder local.

A experiência histórica dos índios de Nova Benavente e de Nova Almeida ainda demonstra uma importante correlação: depois das reformas pombalinas, 
o controle e o acesso às terras dos índios e o exercício do poder local estavam intimamente relacionados, pois a perda de terras entre os indígenas ocorreu pari passu a seu progressivo alijamento dos cargos oficiais das câmaras de suas respectivas vilas e povoações. Assim, depois de um processo de cidanização controlada e de os índios apropriarem-se da cidadania típica do Antigo Regime, seguiu-se um movimento de "descidanização" dos índios, progressivamente alijados dos postos da governança local e novamente considerados ineptos para a política e os negócios da vida pública. $\mathrm{O}$ argumento para se fazer isso era velho e bem conhecido: a suposta inferioridade (civilizacional) dos índios, mesmo daqueles grupos e comunidades com longa história de ressocialização no mundo colonial e que já haviam exercido o governo de suas povoações em décadas anteriores. ${ }^{29}$

O artigo baseia-se em pesquisa financiada pelo Conselho Nacional de Desenvolvimento Científico e Tecnológico ( $\mathrm{CNPq}$ ) no âmbito do programa Bolsa Produtividade em Pesquisa. Sou grata a Maria Fernanda Bicalho e Renata Malcher de Araújo pela leitura crítica do texto e preciosas sugestões.

29 Sobre processos de "cidanização" e "descidanização", cf. Marta Irurozqui Victoriano (2012), que aborda o caso dos índios na Bolívia durante os oitocentos. 


\section{Referências bibliográficas}

ALCIDES, Sérgio. F, L e R: Gândavo e o ABC da colonização. Escritos, Fundação Casa de Rui Barbosa, v. 3, p. 39-53, 2010.

ALMEIDA, Maria Regina Celestino. Metamorfoses indígenas: identidade e cultura nas aldeias coloniais do Rio de Janeiro. Rio de Janeiro: Arquivo Nacional, 2003.

ARENDET, Hannah. A condição humana. 11. ed. Rio de Janeiro: Forense Universitária, 2010. BARTOLOMÉ, Miguel Alberto. As etnogêneses: velhos atores e novos papéis no cenário cultural e politico. Mana, v. 12, n. 1, p. 39-68, 2006.

BICALHO, Maria Fernanda Baptista. O que significa ser cidadão nos tempos coloniais. In: ABREU, Martha; SOIHET, Rachel. Ensino de história: conceitos, temáticas e metodologia. Rio de Janeiro: Casa da Palavra, 2003a. p. 139-151.

. A cidade e o império. Rio de Janeiro: Civilização Brasileira, $2003 \mathrm{~b}$.

BOCCARA, Guillaume. Mundos nuevos en las fronteras del Nuevo Mundo. Nuevo Mundo Mundo Nuevos [online], Debates, 2001, p. 28, online em: 8 fev. 2005. Disponível em: <http:// nuevomundo.revues.org/426>. Acesso em: 14 jan. 2011.

BOXER, C. R. O império colonial português. Lisboa: Edições 70, 1981.

COELHO, Mauro Cezar. A construção de uma lei: o Diretório dos índios. Revista do IHGB, Rio de Janeiro, ano 168, n. 437, p. 29-48, out./dez. 2007.

CUNHA, Manuela Carneiro da. Legislação indigenista do século XIX. São Paulo: Edusp, 1992a. (Org.). História dos índios no Brasil. São Paulo: Companhia das Letras/Secretaria Municipal de Cultura/Fapesp, 1992b. p. 133-154.

FONSECA, Cláudia Damasceno. Funções, hierarquias e privilégios urbanos: a concessão dos títulos de vila e cidade na capitania de Minas Gerais. Varia Historia, n. 29, p. 39-51, jan. 2003.

. Urbs e civitas: a formação dos espaços e territórios urbanos nas Minas setecentistas.

Anais do Museu Paulista, São Paulo, v. 20, n. 1, p. 77-108, jan./jun. 2012.

FRAGOSO, João. A nobreza vive em bandos: a economia política das melhores famílias da terra do Rio de Janeiro. Algumas notas de pesquisa. Tempo, n. 15, p. 11-35, 2003.

GARCIA, Elisa Frühauf. As diversas formas de ser índio. Rio de Janeiro: Arquivo Nacional, 2009. GODINHO, Vitorino Magalhães. Estrutura da antiga sociedade portuguesa. 3. ed. Lisboa: Arcádia, 1977.

GRUZINSKI, Sege. O pensamento mestiço. São Paulo: Companhia das Letras, 2001.

HESPANHA, António Manuel. Imbecillitas: as bem-aventuranças da inferioridade nas sociedades de Antigo Regime. São Paulo: Annablume, 2010a.

. Antigo Regime nos trópicos? Um debate sobre o modelo político do império colonial português. In: FRAGOSO, João; GOUVEA, Maria de Fátima (Org.). Na trama das redes: política e negócios no império português, séculos XVI-XVIII. Rio de Janeiro: Civilização Brasileira, 2010b. HILL, Jonathan D. History, power and identity: ethnogenesis in the Americas, 1492-1992. Iowa: University of Iowa Press, 1996.

KOSTER, Henry. Viagens ao Nordeste do Brasil. Recife: Fundação Joaquim Nabuco/Massangana, 2002. $2 \mathrm{v}$.

LEITE, Serafim. História da Companhia de Jesus no Brasil. Belo Horizonte: Itatiaia 2006. v. 1, t. 1. LOPES, Fátima Martins. Em nome da liberdade: as vilas de índios do Rio Grande do Norte sob o Diretório pombalino no século XVIII. Tese (Doutorado em História), Universidade Federal de Pernambuco, Recife, 2005.

MONTEIRO, John Manuel. Negros da terra: índios e bandeirantes nas origens de São Paulo. São Paulo: Companhia das Letras, 1994.

MONTEIRO, Nuno Gonçalo F. Trajetórias sociais e governo das conquistas: notas preliminares sobre os vice-reis e governadores-gerais do Brasil e da Índia nos séculos XVII e XVIII. In: FRAGOSO, João; BICALHO, Maria Fernanda; GOUVEA, Maria de Fátima. O Antigo Regime nos trópicos. Rio de Janeiro: Civilização Brasileira, 2010b. cap. 8, p. 249-283.

MOREIRA, Vânia Maria Losada. A serviço do império e da nação: trabalho indígena e fronteiras étnicas no Espírito Santo (1822-1860). Anos 90, Porto Alegre, v. 17, p. 13-54, 2010.

. Autogoverno e economia moral dos índios: liberdade, territorialidade e trabalho (Espírito Santo, 1798-1845). Revista de História, USP, v. 166, p. 223-243, 2012.

. Nem selvagens nem cidadãos: os índios da vila de Nova Almeida e a usurpação de suas terras durante o século XIX. Dimensões: Revista de História Ufes, n. 14, p. 151-168, 2002. 
Nós índios, índios nós senhores de nossas ações... Direito de domínio dos índios e cristandade em conflito (vila de Nova Benavente, capitania do Espírito Santo, 1795-1760). In: MOTTA, Márcia; SERRÃO, José Vicente; MACHADO, Marina (Org.). Em terras lusas: conflitos e fronteiras no império português. Vinhedo: Horizonte, 2013.

Territorialidade, casamentos mistos e política entre índios e portugueses. Revista Brasileira de História, São Paulo, 2015. Disponível em: <http://dx.doi.org/10.1590/1806-93472015v35n70006>. OLIVEIRA, José Joaquim Machado de. Notas e apontamentos e notícias para a história da província do Espírito Santo. Revista do IHGB, Rio de Janeiro, t. XIX, n. 22, p. 161-335 e 313-325, 1856. PERRONE-MOISÉS, Beatriz. Índios livres e índios escravos. Os princípios da legislação indigenista no período colonial (séculos XVI a XVIII). In: CUNHA, Manuela Carneiro da (Org.). História dos índios no Brasil. São Paulo: Companhia das Letras/Secretaria Municipal de Cultura/ Fapesp, 1992, p. 115-132.

POMPA, Cristina. Religião como tradução: missionários, tupis e tapuias no Brasil colonial. Bauru: Edusc, 2003.

ROCHA, Levi. Viagem de Pedro II ao Espirito Santo. 3. ed. Vitória: Apees, 2008.

SAINT-HILAIRE, Auguste de. Viagem ao Espírito Santo e Rio Doce. Belo Horizonte: Itatiaia, 1974. SAMPAIO, Patrícia Maria Melo. Vossa Excelência mandará o que for servido...": políticas indígenas e indigenistas na Amazônia portuguesa do final do século XVIII. Tempo, n. 23, p. 39-55, 2007. SCHWARCZ, Lilia Moritz. O espetáculo das raças. São Paulo: Companhia das Letras, 1993.

SCHWARTZ, Stuart; SALOMON, Frank. New peoples and new kinds of people: adaptation, readjustment, and ethnogenesis in South American indigenous societies (colonial era). In:

SALOMON, Frank (Ed.). The Cambridge history of the native people of the Americas: South America. Nova York: Cambridge University Press, 1999. v. III, parte 2.

SILVA, Isabelle Braz Peixoto da. Vilas de índios no Ceará Grande. Campinas: Pontes, 2005.

SOMMER, Barbara Ann. The Amazonian native nobility in late-colonial Pará. In: LANGFUR, Hall (Ed.). Native Brazil — beyond the convert and the canibal, 1500-1900. Albuquerque: University of New Mexico Press, 2014. p. 108-131.

SPIX, Johann Baptist von; MARTIUS, Karl Friedrich Philipp von. Viagem pelo Brasil, 1817-1820. São Paulo: Universidade de São Paulo; Belo Horizonte: Itatiaia, 1981. v. 1.

VAINFAS, Ronaldo. A heresia dos índios: catolicismo e rebeldia no Brasil colonial. São Paulo: Companhia das Letras, 1995.

VIANA, Larissa. O idioma da mestiçagem: as irmandades de pardos na América portuguesa. Campinas: Unicamp, 2007.

VICTORIANO, Marta Irurozqui. Tributo y armas en Bolivia: comunidades indígenas y estratégias de visibilización ciudadana, siglo XIX. Mundo Agrario, v. 13, n. 25, dez. 2012. Disponível em: <http://www.mundoagrario.unlp.edu.ar/>. 